\title{
PENYULUHAN ORANG TUA DALAM MENDUKUNG PENDIDIKAN ANAK SEBAGAI FASILITATOR BELAJAR
}

\author{
Widiastuti $^{1}$, Yubali Ani ${ }^{2}$, Ashiong Parhehean Munthe ${ }^{3}$ \\ ${ }_{123}$ Universitas Pelita Harapan
}

Widiastuti.tc@uph.edu, yubali.ani@uph.edu, ashiong.munthe@uph.edu

\begin{abstract}
Abstrak
Berdasarkan hasil evaluasi dari pelaksanaan progam Edunation selama dua tahun terakhir, bahwa masih terdapat beberapa fasilitator belajar yang mengundurkan diri di tengah-tengah berlangsungnya pelatihan fasilitator belajar. Hal ini dikarenakan kurangnya dukungan dari orang tua mereka, beberapa orang tua beranggapan bahwa program Edunation ini tidak penting dan membuang waktu sehingga anak tidak bisa membantu orang tua bekerja mencari uang. Pada hal, program ini merupakan salah satu bentuk kompensasi beasiswa yang sudah mereka terima dari Yayasan Emmanuel. Oleh karena itu, diperlukan penyuluhan bagi orang tua yang anaknya ikut serta dalam pelatihan fasilitator belajar. Tujuan dari penyuluhan ini adalah untuk memberikan gambaran tentang manfaat program Edunation dan peran orang tua dalam mendukung pendidikan anak. Metode kegiatan dilakukan dengan menganalisis situasi terlebih dahulu, kemudian menyusun materi yang dibutuhkan, menyusun rencana pelaksanaan penyuluhan dan terakhir melakukan evaluasi kegiatan penyuluhan. Adapun hasil dari kegiatan penyuluhan tersebut adalah 1.) Orang tua mengetahui pentingnya pendidikan bagi masa depan anak; 2.) Orang tua memiliki pengetahuan bagaimana mendukung anak dalam menjalankan pendidikan; 3.) Orang tua mengetahui tujuan dan manfaat dari anak mengikuti pelatihan fasilitator belajar; 4.) Orang tua mengetahui dampak dari anak menjadi fasilitator belajar di lingkungan mereka; 5.) Orang tua memberikan dukungan terhadap anaknya dalam mengikuti pelatihan sebagai fasilitator belajar. Dengan demikian dapat disimpulkan bahwa kegiatan penyuluhan orang tua efektif untuk memberikan gambaran bagi para orang tua tentang pentingnya pendidikan bagi anak dan manfaat program Edunation.
\end{abstract}

Kata kunci: orang tua, pendidikan anak, fasilitator belajar.

\section{PENDAHULUAN}

Program Edunation merupakan program beasiswa yang diberikan oleh Yayasan Emmanuel kepada siswa SMA dan SMK di Bogor. Program ini berlangsung untuk memberikan keringanan biaya sekolah bagi siswa yang kurang mampu. Kompensasi dari beasiswa tersebut adalah para siswa SMA \& SMK yang sudah mendapatkan beasiswa dituntut untuk memiliki kepedulian terhadap lingkungan sekitar yaitu dibidang pendidikan. Oleh karena itu, mereka diminta untuk membantu belajar anak-anak dari jenjang PAUD-SMP dilingkungan tempat tinggal mereka dengan menjadi fasilitator belajar.

Pada umumnya fasilitator belajar merupakan seseorang yang memudahkan orang lain belajar. Hal ini sesuai dengan pendapat dari Suyanto dan Jihad (2013) tentang fasilitator adalah seseorang yang menyediakan kemudahan-kemudahan bagi siswa 
dalam proses belajar mengajar. Lebih lanjut lagi fasilitator adalah kemampuan seseorang baik secara perorangan maupun kelompok yang membantu sekelompok orang lain dalam mencapai tujuan tertentu (Kadir,dkk, 2006 dalam Agung, 2017). Sedangkan belajar adalah proses perubahan perilaku baru secara keseluruhan sebagai hasil dari pengalaman individu itu sendiri dalam berinteraksi dengan lingkungannya (Mohmmad Surya, 1997 dalam Kosasih, 2016). Dengan demikian yang dimaksud dengan fasilitator belajar adalah seseorang yang bersedia memberikan kemudahan bagi orang lain dalam mengubah perilakunya secara keseluruhan.

Lebih lanjut Supeno dalam Kanan dan Yulianingsih (2018) menggemukakan bahwa empat fungsi utama fasilitator dalam pemberdayaan masyarakat adalah sebagai narasumber, pelatih, mediator, dan pengerak. Sedangkan peran fasilitator belajar menurut Roestiyah (2001) dalam Warisdiono, Sarma, Gani, dan Susanto (2013) adalah sebagai pelatih, pemandu, desainer lingkungan belajar, model dan mentor, dan evaluator. Dalam hal ini, para fasilitator belajar membantu dan memberikan kemudahan bagi masyarakat sekitar mereka yaitu membantu belajar anak-anak jenjang PAUD sampai SMP. Para fasilitator belajar bukan saja menjadi narasumber belajar, namun mereka juga sebagai mediator bagi para orang tua yang kurang mampu mengajar anak-anak mereka dalam belajar di rumah, melatih belajar secara berkelanjutan, dan menjadi pengerak dalam masyarakat dalam meningkatkan kepedulian terhadap pendidikan dilingkungan sekitar.

Peserta dalam kegiatan fasilitator belajar dilingkungan sekitar mereka disebut sebagai partisipan atau disingkat dengan PP. Partisipan (PP) tersebut merupakan siswa-siswa yang ikut serta dalam kelompok belajar di jenjang PAUD-SMP yang akan difasilititasi oleh fasilitator belajar yang sudah dilatih sebelumnya. Untuk melatih para fasilitator belajar ini mampu menjadi fasilitator, maka dibutuhkan tenaga untuk menguasai bidang pendidikan dan muatan materi. Dengan demikian, untuk memperlengkapi para fasilitator belajar ini dilakukanlah kegiatan pelatihan fasilitator belajar.

Kegiatan pelatihan fasilitator belajar tersebut telah berlangsung selama dua tahun dengan perserta yang berbeda setiap tahunnya. Berdasarkan hasil evaluasi dari beberapa angkatan didapati beberapa masalah yang perlu dibenahi, yaitu: 1) Beberapa perserta mengundurkan diri ditengah berlangsungnya pelatihan dengan alasan harus membantu orang tua bekerja; 2) Orang tua tidak memahami dampak, fungsi, dan manfaat pelatihan fasilitator belajar bagi anak mereka, sehingga program ini dianggap tidak penting dan membuat waktu bagi anak-anak mereka; 3) Masih rendahnya pengetahuan orang tua dalam memandang pendidikan bagi anak-anaknya; 4) Kurangnya dukungan atau motivasi dari orang tua terhadap peran anaknya sebagai fasilitator belajar dilingkungan tempat mereka tinggal.

Berdasarkan permasalahan tersebut maka penting sekali dilakukan kegiatan penyuluhan terhadap orang tua dalam mendukung pendidikan anak sebagai fasilitator belajar. Tujuan dari kegiatan penyuluhan ini adalah untuk memberikan gambaran yang utuh dan jelas tentang tujuan dan manfaat program Edunation dan peran orang tua dalam mendukung pendidikan anak. Melalui kegiatan penyuluhan ini diharapkan orang tua dapat semakin memahami pentingnya pendidikan bagi masa depan anak mereka, memiliki pengetahuan yang benar dalam mendukung anak mereka dalam menjalankan pendidikan, orang tua dapat memahami tujuan dan manfaat dari anak mengikuti pelatihan fasilitator belajar, orang tua dapat menyadari dampak yang besar dari anak mereka menjadi fasilitator belajar dilingkungan mereka, dan terakhir orang tua dapat memberikan dukungan terhadap anak mereka dalam mengikuti pelatihan sebagai fasilitator belajar. Dengan demikian, melihat tujuan dan manfaat di atas maka kegiatan penyuluhan orang tua ini sangat penting dilakukan.

\section{METODE}

Adapun metode yang digunakan dalam kegiatan punyuluhan orang tua ini antara lain: 1) Menganalisis kendala yang dihadapi para siswa saat mengikuti pelatihan; 2) Menyusun materi sesuai dengan analisis kebutuhan; 3) Menyusun rencana pelaksanan penyuluhan: penyuluhan materi sekitar 1-2 jam, diskusi dan tanya jawab dengan orang tua serta para fasilitator belajar; 4) Evaluasi kegiatan penyuluhan. 


\section{HASIL DAN PEMBAHASAN}

Kegiatan penyuluhan orang tua dalam mendukung pendidikan anak sebagai fasilitator belajar telah terlaksana pada hari Sabtu, 8 Februari 2020 pukul 10.00 -12.00 WIB di SMK NU Cijeruk, Cihideng, Bogor. Jumlah peserta sebanyak 33 orang tua. Satu orang tua tidak hadir. Selain orang tua, hadir juga 34 siswa SMA/SMK calon fasilitator belajar angkatan 2020. Adapun susunan acara kegiatan penyuluhan orang tua adalah sebagai berikut:

Tabel 1. Susunan Acara Penyuluhan Orang Tua

\begin{tabular}{|c|c|}
\hline Waktu & Kegiatan \\
\hline $10.00-10.10$ & Pembukaan \& doa \\
\hline $10.10-10.20$ & Kata Sambutan \\
\hline $10.20-11.10$ & $\begin{array}{l}\text { Penyampaian materi } \\
\text { penyuluhan orang tua }\end{array}$ \\
\hline $11.10-11.40$ & Penyampaian tujuan \\
\hline $11.40-12.00$ & Pelatihan fasilitator belajar \\
\hline $12.00-13.00$ & Diskusi dan tanya jawab \\
\hline $13.00-14.00$ & Isoma \\
\hline & $\begin{array}{l}\text { Perkenalan pengajar, } \\
\text { Mentor dan fasilitator belajar }\end{array}$ \\
\hline $14.00-14.10$ & Penutup \& doa \\
\hline
\end{tabular}

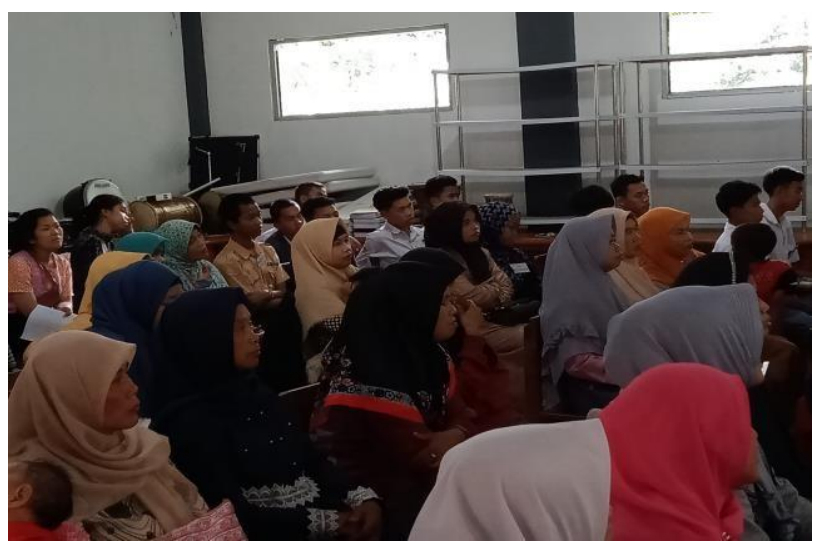

Gambar 1. Para orang tua peserta penyuluhan Kegiatan penyuluhan orang tua dalam mendukung pendidikan anak sebagai fasilitator belajar telah terlaksana dengan baik. Hampir seluruh orang tua hadir dalam kegiatan penyuluhan ini. Hal ini menunjukkan respon yang baik dari para orang tua terhadap kegiatan penyuluan ini, meskipun terdapat satu orang tua yang tidak hadir dikarenakan bekerja. Pelaksanaan kegiatan penyuluhan orang tua juga dimulai tepat waktu. Setiap susunan acara yang telah tersusun terlaksana sesuai dengan yang direncanakan.

Kegiatan penyuluhan disampaikan dengan metode caramah interaktif, dimana terdapat tanya jawab langsung antara pemateri dan para orang tua. Para orang tua juga terlihat antusias dan berinteraksi dengan cukup terbuka sehingga suasana penyuluhan berlangsung menarik. Terlebih ketika diberikan kesempatan untuk menyampaikan pendapat orang tua dan juga pendapat anak. Hal ini menjadi kesempatan untuk menyamakan persepsi dari kedua belah pihak yaitu harapan dari sisi orang tua maupun dari sisi anak.

Berdasarkan hasil tanya jawab dengan orang tua selama kegiatan penyuluhan berlangsung maka di dapati hasil sebagai berikut:

\section{Orang tua mengetahui pentingnya pendidikan bagi masa depan anak.}

Pendidikan merupakan hak asasi manusia. Sebagaimana dalam UU No. 33/1999 pasal 60 ayat 1 yang menyatakan bahwa setiap anak berhak untuk memperoleh pendidikan dan pengajaran dalam rangka pengembangan kepribadiannya sesuai dengan minat, bakat, dan tingkat kecerdasannya. Dengan demikian berdasarkan undang-undang tersebut setiap anak berhak memperoleh pendidikan.

Pendidikan berawal dari keluarga. Orang tua merupakan pendidik utama dalam sebuah keluarga bagi anak-anak mereka. Hal ini sesuai dengan pendapat Umar (2015) bahwa orang tua merupakan sosok utama dan pertama dalam pendidikan anak. Orang tua memiliki peran dan tanggungjawab dalam mendidik anak-anaknya. Menurut Sari (2017) peran orang tua dalam dunia pendidikan adalah sebagai pendidik, pendorong atau motivator, fasilitator, dan pembimbing. Peran sebagai pendidik, orang tua bertanggungjawab mengupayakan seluruh potensi dalam diri anak, baik kognitif, afektif, maupun psikomotor. Peran sebagai pendorong atau motivator adalah memberikan dorongan dan dukungan penuh serta memotivasi anak untuk belajar. Peran sebagai fasilitator adalah memenuhi fasilitas belajar agar proses belajar dapat berjalan dengan lancar. Terakhir peran orang tua dalam membimbing serta mengarahkan anaknya dalam menjalankan proses pendidikan. 


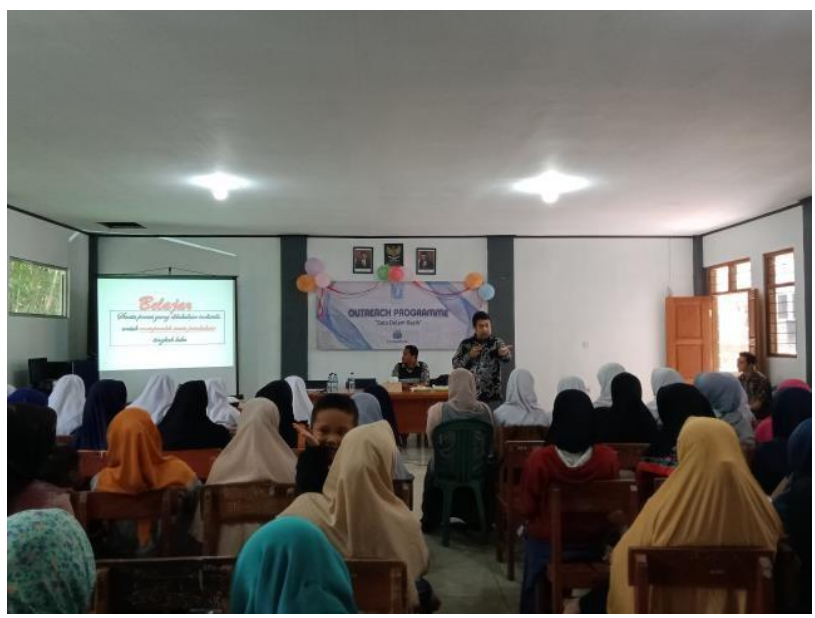

Gambar 2. Penyampaian materi penyuluhan

Setelah mengikuti kegiatan penyuluhan didapati bahwa para orang tua mendapatkan gambaran yang jelas tentang pentingnya pendidikan bagi masa depan anaknya. Berdasarkan hasil tanya jawab selama kegiatan penyuluhan berlangsung didapati bahwa sebagian besar orang tua menjawab bahwa pendidikan anak itu sangat penting. Pendidikan memberikan harapan yang besar akan masa depan yang lebih baik bagi anak-anak mereka. Dari kegiatan penyuluhan ini para orang tua kembali disadarkan bahwa orang tua juga memiliki peran dalam mendukung dan memfasilitasi pendidikan anak-anak mereka.

\section{Orang tua memiliki pengetahuan bagaimana mendukung anak dalam menjalankan Pendidikan.}

Setelah mendapatkan pemahaman tentang pentingnya pendidikan bagi masa depan anak, para orang tua juga memiliki kesadaran akan pentingnya memberikan dukungan anaknya dalam menjalankan pendidikan. Pendidikan bukan saja meliputi bersifat informal di dalam keluarga namun juga bersifat formal dan non formal. Hal ini sebagaimana dikemukakan oleh Dariyo dalam Siregar (2013) terdapat tiga jenis pendidikan yaitu informal, formal, dan non formal. Pendidikan informal merupakan jalur pendidikan di dalam keluarga dan lingkungan. Bentuknya berupa kegiatan belajar mandiri. Sedangkan pendidikan formal adalah pendidikan yang diselenggarakan di sekolah-sekolah pada umumnya. Pendidikan non formal merupakan pendidikan yang diluar jalur pendidikan formal yang berfungsi untuk mengembangkan potensi yang menekankan pada pengetahuan dan keterampilan fungsional, pengembangan sikap dan kepribadian professional. Dalam hal ini, kegiatan pelatihan fasilitator belajar yang diikuti para siswa SMA-SMK termasuk ke dalam pendidikan non formal. Mereka dilatih untuk mengembangkan potensi mereka dalam mengajar, memiliki pengetahuan akan materi-materi yang akan diajarkan dan keterampilan fungsional seperti membuat perencanaan pembelajaran, membuat media pembelajaran, alat peraga, serta membuat penilaian. Selain itu mereka juga dapat mengembangkan sikap dan kepribadian mereka seperti percaya diri, keberanian, bekerjasama, dan memecahkan masalah.

Melihat pentingnya seluruh pendidikan baik informal, formal, maupun non formal tersebut maka penting sekali para orang tua memberikan dukungan penuh terhadap seluruh proses pendidikan tersebut. Menurut Keraf dalam Siregar (2013) dukungan tersebut dapat berupa memberikan rasa aman pada anak, mengajarkan hal-hal yang baik, memberikan pandangan dan berperilaku yang benar pada anak, menjadi teladan yang baik, dan tidak berhenti belajar dan terus memperbaiki cara mendidik anak, menyediakan makanan sehat dan lingkungan yang baik bagi pertumbuhan anak. Dengan demikian, melalui dukungan orang tua tersebut anak juga akan merasa nyaman dan termotivasi dalam menjalankan proses pendidikannya.

\section{Orang tua mengetahui tujuan dan manfaat dari anak mengikuti pelatihan fasilitator belajar.}

Berdasarkan hasil evaluasi kegiatan fasilitator belajar selama dua tahun di dapati bahwa masih banyak orang tua yang merasa bahwa kegiatan program Edunation berupa pelatihan fasilitator belajar ini adalah kegiatan yang membuang-buang waktu. Banyak orang tua beranggapan kegiatan pelatihan fasilitator belajar tersebut tidak memiliki manfaat bagi anak-anak mereka. Oleh karenanya, para orang tua sering menuntut anaknya untuk tidak melanjutkan kegiatan pelatihan fasilitator belajar dan meminta mereka untuk bekerja membantu orang tua mereka. Memang tidak dapat dipungkiri bahwa kondisi status ekonomi menjadi salah satu alasan 
utama para orang tua memaksa anak mereka untuk bekerja. Ketidaktahuan akan tujuan dan manfaat suatu kegiatan tentu membuat seseorang tidak menganggap bahwa kegiatan tersebut penting.

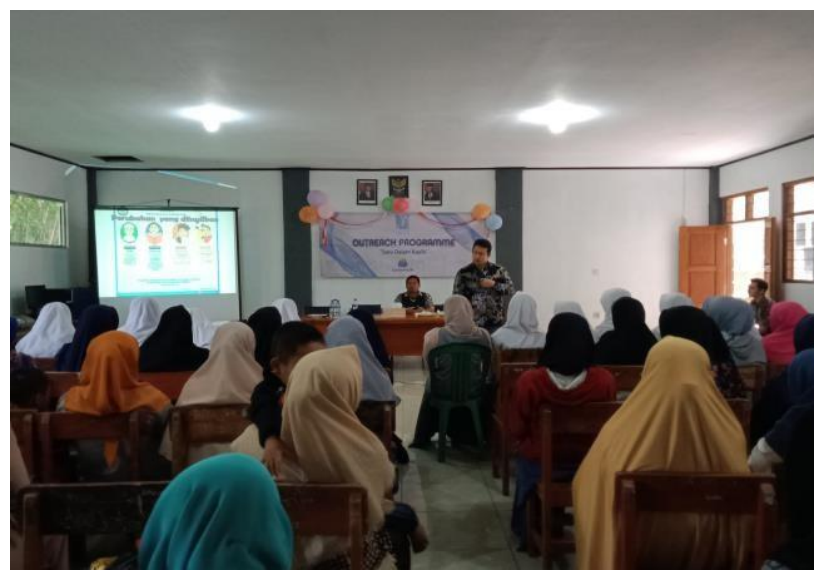

Gambar 3. Sesi tanya jawab

Melalui kegiatan penyuluhan orang tua ini membukakan pemikiran mereka terhadap kegiatan pelatihan fasilitator belajar. Orang tua menjadi sadar bahwa kegiatan ini bukan sekedar kegiatan membuang waktu sebagaimana terungkap pada hasil evaluasi selama dua tahun terakhir. Pelatihan fasilitator belajar ini memiliki tujuan utama yaitu untuk meningkatkan rasa kepedulian terhadap lingkungan masyarakat khususnya dalam bidang pendidikan. Kegiatan pelatihan fasilitator belajar ini juga bertujuan untuk memperlengkapi para fasilitator belajar dalam mengasah keterampilan mengajarnya. Para fasilitator belajar diperlengkapi secara holistik atau menyeluruh dari seluruh aspek baik itu kognitif, afektif, maupun psikomotorik.

Secara kognitif para fasilitator belajar diperlengkapi dengan pengetahuan-pengetahuan tentang materi-materi dari berbagai bidang studi seperti Bahasa Indonesia, Matematika, IPA, IPS, Kewarganegaraan dan Seni budaya. Selain materi mereka juga mendapatkan pengetahuan tentang strategi mengajar, metode-metode mengajar, penilaian. Dari aspek afektif mereka dilatih dalam hal percaya diri, berani tampil didepan umum, berkerjasama dan menyelesaikan masalah. Aspek psikomotorik mereka dilatih dalam hal keterampilan mengajar melalui microteaching, membuat media pembelajaran, membuat alat peraga, keterampilan berbicara atau berkomunikasi.

Melihat materi-materi pelatihan fasilitator belajar yang begitu lengkap sebagaimana mereka hendak menjadi guru, tentu hal ini memberikan gambaran yang jelas bagi para orang tua bahwa kegiatan pelatihan ini sungguh-sungguh memiliki segudang manfaat yang positif bagi perkembangan anak mereka. Anak-anak mereka tentunya mendapatkan pengetahuan lebih dari anakanak lainnya, dapat memanfaatkan waktu dengan baik untuk kegiatan pelatihan dibandingkan untuk kegiatan yang tidak bermanfaat, dapat mengembangkan sikap dan kepribadian mereka menjadi lebih baik lagi, dan memiliki keterampilan mengajar sebagaimana tujuan utama dari pelatihan ini.

Gambaran yang utuh tentang tujuan dan manfaat dari kegiatan pelatihan fasilitator belajar yang begitu banyak dari tentunya membukakan kesadaran para orang tua untuk mendukung penuh penuh kegiatan pelatihan ini. Hal ini sesuai dengan pendapat Siregar (2016) terkait dengan kesadaran. Kesadaran merupakan sesuatu yang bersifat intensionalitas atau bertujuan. Artinya, kesadaran itu sendiri tidak dapat dibayangkan tanpa sesuatu yang disadari. Dengan demikian, kesadaran mendorong seseorang menentukan respon selanjutnya. Dalam hal ini kesadaran orang tua akan tujuan dan manfaat kegiatan pelatihan fasilitator belajar mendorongnya untuk memberikan respon positif yaitu berupa dukungan penuh pada anak mereka dalam mengikuti pelatihan ini.

\section{Orang tua mengetahui dampak dari anak menjadi fasilitator belajar di lingkungan mereka.}

Kegiatan pelatihan fasilitator belajar ini bukan saja sekedar memperlengkapi para siswa SMA-SMK memperoleh pengetahuan dan keterampilan mengajar. Namun, kegiatan pelatihan fasilitator belajar ini memiliki tujuan utama yaitu fasilitator belajar dapat menjalankan perannya dalam masyarakat yaitu memberikan bantuan belajar bagi anak-anak partisipan dilingkungan sekitar rumah mereka. Fasilitator belajar dapat mempraktekkan langsung materi-materi yang sudah merekadapatkan dari pelatihan ke kelas-kelas belajar mereka masingmasing. Mereka dapat merancang pembelajaran, strategi dan metode belajar, merancang permainan, alat peraga, media pembelajaran dan juga penilaian terhadap proses belajar mengajar yang mereka lakukan pada anak-anak partisipan dilingkungan sekitar rumah mereka. 
Melalui kegiatan penyuluhan orang tua ini membukakan pemikiran tentang dampak kegiatan pelatihan fasilitator belajar secara lebih luas. Kegiatan pelatihan fasilitator belajar ini tidak hanya memberikan dampak positif bagi anak mereka secara pribadi namun juga memiliki dampak yang lebih luas yaitu mengembangkan pendidikan dilingkungan sekitar rumah mereka. Tentu hal ini menjadi suatu kebanggaan tersendiri bagi para orang tua ketika melihat anaknya berguna dan bermanfaat bagi masyarakat luas.

\section{Orang tua memberikan dukungan terhadap anaknya dalam mengikuti pelatihan sebagai fasilitator belajar.}

Ketika para orang tua mendapatkan gambaran yang utuh tentang tujuan dan manfaat dari program Edunation berupa palatihan fasilitator belajar dan membantu belajar anak-anak partisipan dilingkungan mereka, para orang tua sepakat untuk memberikan dukungan penuh pada anak-anak mereka dalam mengikuti kegiatan pelatihan fasilitator belajar ini. Menurut Ellis, Thomas, \& Rollins yang dikutip Tan, Ismanto, dan Babakal (2013) dukungan orang tua merupakan interaksi yang dikembangkan orang tua yang dicirikan oleh perawatan, kehangatan, persetujuan, dan berbagai perasaan positif orang tua terhadap anak. Dalam hal ini, persetujuan dari pihak orang tua untuk anaknya didik dalam kegiatan pelatihan fasilitator belajar. Selain itu juga perasaan positif bahwa anaknya akan mendapatkan pendidikan dan pengalaman yang lebih baik serta berdampak bagi masyarakat luas tentunya memberikan rasa puas dan bangga dalam diri orang tua. Oleh karena itu, dukungan penuh terhadap terlaksananya kegiatan pelatihan fasilitator belajar ini sangat besar diberikan dari para orang tua.

Selain itu, dukungan dari para orang tua terhadap kegiatan pelatihan fasilitator belajar ini juga dengan memperingatkan pada anak-anak mereka untuk disiplin mengikuti setiap sesi pelatihan yang akan dilakukan selama setahun ke depan. Para orang tua sepakat untuk menegur, menasehati, dan mendorong anaknya untuk aktif mengikuti kegiatan pelatihan. Melalui dukungan penuh dari orang tua tentunya dapat menjadi semangat bagi para fasilitator belajar untuk dapat mengikuti kegiatan pelatihan fasilitator belajar secara maksimal. Para fasilitator belajar dapat belajar tanpa merasa ketakutan akan berhenti ditengah jalan dengan alasan membantu orang tua bekerja. Justru dengan dukungan penuh yang diberikan oleh orang tua, para fasilitator belajar menjadi lebih bertanggungjawab terhadap perkerjaan rumah, tugas belajar di sekolah, maupun tugas belajar dipelatihan fasilitator belajar.

Orang tua bukan saja memberikan dukungan penuh pada anak-anak mereka dalam mengikuti pelatihan fasilitator belajar. Para orang tua juga memberikan dukungan penuh bagi anak-anak mereka untuk menjadi fasilitator belajar bagi anakanak partisipan di lingkungan sekitar rumah mereka. Tentu dukungan ini disambut baik dari para fasilitator belajar. Para orang tua mempersilahkan rumah mereka sebagai tempat untuk kegiatan belajar bagi anak-anak partisipan sehingga hal ini memudahkan para fasilitator belajar dalam melaksanakan praktek mengajar mereka pada anakanak partisipan.

\section{Kegiatan tambahan diluar penyuluhan orang tua.}

Selain kegiatan penyuluhan orang tua, kegiatan ini juga memberikan kesempatan bagi para fasilitator belajar untuk bertemu langsung dengan para mentor yang akan membimbing mereka selama pelatihan fasilitator belajar berlangsung dalam kelompok kecil. Selain itu para fasilitator juga bertemu langsung dengan anggota kelompoknya. Kesempatan ini menjadi waktu untuk saling mengenal satu sama lain, saling membangun kerjasama, dan saling memberikan dukungan satu sama lain. Selain itu, mereka juga mengenal prosedur yang akan berlaku selama pelatihan fasilitator belajar berlangsung. Dengan demikian mereka dapat mengikuti dengan tertip setiap kegiatan dalam pelatihan fasilitator belajar. Hal ini menjadi titik awal bagi para fasilitator belajar dan mentor untuk mempersiapkan diri dalam kegiatan pelatihan selanjutnya. 


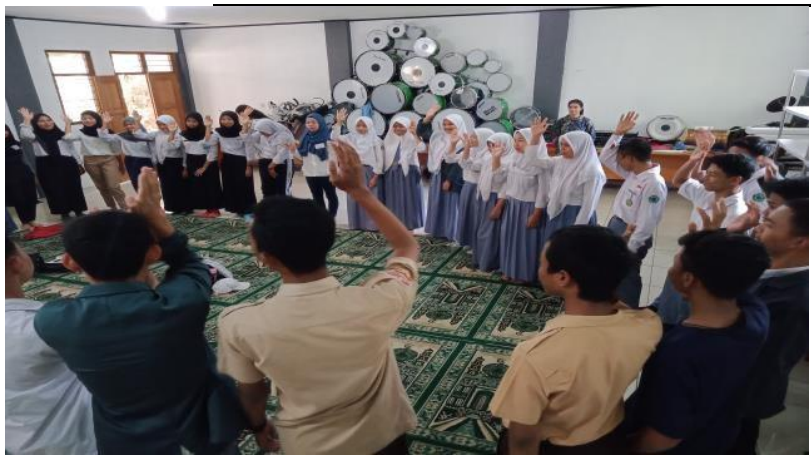

Gambar 5: Pengenalan Prosedur Kelas

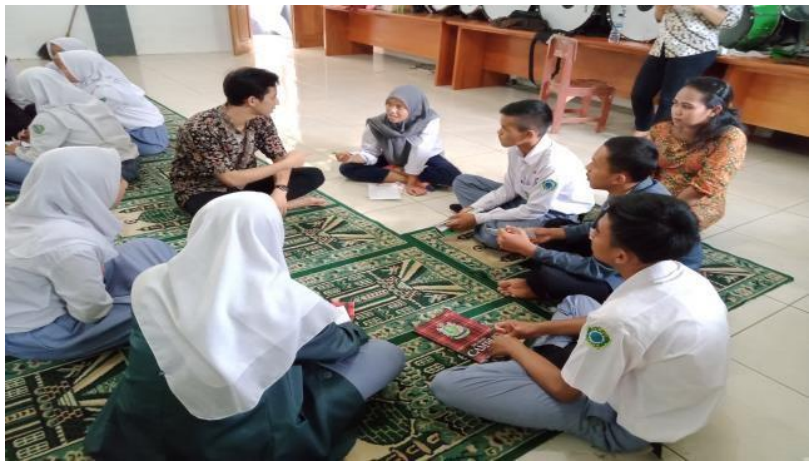

Gambar 6: Perkenalan Anggota Kelompok Bersama Mentor

Dampak dari kegiatan penyuluhan orang tua ini adalah adanya kesadaran dari orang tua tentang pentingnya pendidikan bagi anak. Pendidikan yang dimaksud bukan hanya meliputi pendidikan formal, namun juga pendidikan informal dan non formal. Para orang tua juga mengambil suatu tindakan nyata dalam mendukung anak-anak mereka mengikuti kegiatan pelatihan fasilitator belajar. Selain itu mereka juga memberikan dorongan penuh bagi para anak-anak mereka untuk menjadi fasilitator belajar disekitar rumah mereka. Dengan demikian, para anak mendapatkan dukungan penuh dari para orang tua untuk mengikuti program pelatihan fasilitator belajar.

\section{KESIMPULAN}

Berdasarkan pemaparan hasil kegiatan penyuluhan orang tua maka tujuan dari kegiatan penyuluhan ini tercapai. Kegiatan ini efektif untuk memberikan gambaran bagi para orang tua tentang pentingnya pendidikan bagi anak dan manfaat program Edunation. Para orang tua memahami pentingnya pendidikan baik informal, formal maupun non formal bagi anak-anak mereka. Para orang tua mendapatkan gambaran yang jelas tujuan, manfaat, dan dampak positif bagi anak mereka maupun lingkungan. Para orang tua memiliki juga gambaran yang utuh dari kegiatan pelatihan fasilitator belajar yang diikuti anak-anaknya. Selain itu, para orang tua juga memberikan dukungan terhadap anak-anak mereka dalam mengikuti kegiatan pelatihan fasilitator belajar maupun juga dalam menjalankan kegiatan fasilitator belajar bagi anak-anak partisipan dilingkungan sekitar rumah mereka.

Melihat dari keberhasilan dari kegiatan penyuluhan orang tua ini dan dampak yang cukup besar bagi orang tua dan anak, maka kegiatan penyuluhan orang tua ini dapat dilakukan secara berkala. Adapun rekomendasi topik-topik penyuluhan yang diangkat dapat berupa pola asuh orang tua terhadap anak remaja, membangun komunikasi yang baik dengan anak, memahami anak pada masa remaja dan lain sebagainya. Dengan demikian, diharapkan melalui topik-topik tersebut dapat menolong orang tua dalam mengasuh dan memenuhi kebutuhan anak-anak mereka dengan benar.

\section{UCAPAN TERIMAKASIH}

Terima kasih kepada Yayasan Emmanuel atas kerjasama yang baik selama proses pelaksanaan kegiatan penyuluhan orang tua dalam mendukung pendidikan anak sebagai fasilitator belajar. Terima kasih juga kepada Program Studi Pendidikan Guru Sekolah Dasar, Universitas Pelita Harapan atas dukungannya selama berlangsungnya kegiatan penyuluhan ini (PM-003-M/FIP/I/2020).

\section{REFERENSI}

Agung I. (2017). Peran Fasilitator Guru Dalam Penguatan Pendidikan Karakter (PPK). Jurnal Perspektif Ilmu Pendidikan, 31 (2): 106-119.

Eko Warisdiono E., Sarma M., Gani D.S., Susanto D. (2013). Kompetensi Fasilitator Pelatihan Pusat Pengembangan dan Pemberdayaan Pendidik dan Tenaga Kependidikan Pertanian (P4TK Pertanian) Kementrian Pendidikan dan Kebudayaan.. Jurnal Penyuluhan, 9 (2): 109-119.

Kanan, M., Yulianingsih, W. (2018) Peran fasilitator dalam meningkatkan 
kemandirian anak jalanan melalui kelompok belajar paket c "suket teki" di kota Kediri. $J+$ Plusunesa,7(1):1-8.

Kosasih. (2016). Strategi Belajar dan Pembelajaran: Imlementasi Kurikulum 2013. Bandung: Penerbit Yrama Widya.

Sari, D. (2017). Peran Orang Tua dalam Memotivasi Belajar Siswa. Prosiding Seminar Nasional 20 Program Pascasarjana Universitas PGRI Palembang.

Siregar, N.S.S. (2013). Persepsi Orang Tua terhadap Pentingnya Pendidikan bagi Anak. Jurnal Ilmu Pemerintahan dan Sosial Politik UMA, 1 (1): 11-27.

Siregar, N.S.S. (2016). Kesadaran Masyarakat Nelayan Terhadap Pendidikan Anak. Jurnal Ilmu Pemerintah dan Ilmu Sosial Politik UMA, 4 (1): 25491660.
Suyanto \& Jihad, A. (2013). Menjadi Guru Profesional: Strategi Meningkatkan Kualifikasi dan Kualitas Guru di Era Global. Jakarta: Esensi Erlangga Group.

Tan, J.H., Ismanto, A.Y \& Babakal, A. (2013). Hubungan Antara Dukungan Orang Tua dan Motivasi Belajar Pada Anak Usia Sekolah kelas IV dan V di SD Negeri Kawangkoan Kalawat. Ejournal Keperawatan (e-Kp) Volume 1 No. 1 Agustus 2013.

Umar, M. (2015). Peranan Orang tua dalam Peningkatan Belajar Anak. Jurnal Ilmiah Edukasi Vol 1, Nomor 1, Juni 2015. 